\title{
ANGUILLICOLA CRASSUS LARVAE IN CORMORANT'S PREY FISH IN VISTULA LAGOON, POLAND.
}

\author{
T. WLASOW (1), P. GOMULKA (1), A. MARTYNIAK (1), S. BORON (1), \\ P. HLIWA (1), J. TERLECKI (1), U. SZYMANSKA (2)
}
(1) Faculty of Water Protection and Inland Fisheries, University of Agriculture and Technology, 10-975 Olsztyn - Kortowo, Poland.
(2) Training Teachers College, 10-561 Olsztyn, Poland.

\begin{abstract}
The presence of $A$. crassus larvae in herring, stickleback, perch, ruffe, pike-perch, bream and roach regurgitated by cormorants from a large breeding colony at Katy Rybackie in Vistula Lagoon, Poland, was investigated. Larvae of nematode were detected only in ruffe, the dominant species in the diet of the cormorant $(58 \%$ of the weight of fish consumed). Mean intensity of infection was 1.57 larva per infected host (max. 5.0) and mean abundance was 0.52 larva per examined ruffe. On the basis of the infection rate $(33.3 \%)$, it was estimated that cormorants eliminated 150 tons of infected ruffe yearly.
\end{abstract}

Key-words : Anguillicola, cormorant, prey fish, Vistula Lagoon.

\section{LES LARVES D'ANGUILLICOLA CRASSUS DANS LES POISSONS ÉLIMINÉS PAR LES CORMORANS, DANS LA BAIE DE VISTULE EN POLOGNE.}

\section{RÉSUMÉ}

La présence de stades larvaires d'Anguillicola crassus a été examinée chez le hareng, l'épinoche, la perche, la grémille, le sandre, la brème et le gardon. Tous ces poissons ont été régurgités par les cormorans vivant dans une colonie de nidification appelée Katy Rybackie, près de la Baie de Vistule en Pologne. Des larves de ce nématode ont été trouvées seulement chez la grémille, l'espèce prédominante dans la nourriture du cormoran (58\% du total pondéral des poissons consommés). Vu la prévalence de l'invasion, il a été possible d'estimer que les cormorans éliminent chaque année environ 150 tonnes de grémilles contaminées. L'intensité moyenne de la contamination par A. crassus était de 1.57 larve par poisson (maximum 5.0) et le taux d'invasion était de 0.52 larve par poisson examiné.

Mots-clés : Anguillicola, cormoran, poisson proie, Baie de Vistule.

\section{INTRODUCTION}

The first outbreak of the European eel anguillicolosis in Japanese farm ponds described by EGUSA (1979) was a vain warning for practice. The Asiatic nematode 
Anguillicola crassus has been unintentionally introduced into many European countries, first Italy (PAGGl et al., 1982) and Germany (KOOPS and HARTMANN, 1987), then the Netherlands (DEKKER and VAN WILLIGEN, 1987), Belgium, Denmark, England, Greece, Spain, France, Austria (BELPAIRE et al., 1989), Poland (WLASOW et al., 1991). At present, A. crassus is observed in 15 European countries (HÖGLUND and ANDERSON, 1993 ; MORAVEC, 1994).

The role of human activity and natural ways of spreading of $A$. crassus with infected eel and other fish species - paratenic hosts, as well as the role of intermediate hosts (zooplankton) are already known (BELPAIRE et al., 1989 ; DE CHARLEROY et al., 1987). But it is still unclear if birds, especially cormorants, may be responsible for $A$. crassus distribution. If so, it could be another guild of cormorants which are already charged with preying on eel.

In spring 1996, investigations on parasitical fauna, especially $A$. crassus infection, of fish preyed by cormorants and fish from Vistula Lagoon were started. The study was part of a research programme on the influence of cormorants on Vistula Lagoon fish community. This programme was sponsored by the Sea Office in Gdynia and the State Office of Nature Reserve in Elblag, Poland.

This paper presents some preliminary data on the occurrence of $A$. crassus in cormorant's prey fish from the large breeding colony at Katy Rybackie next to Vistula Lagoon, Poland.

\section{MATERIAL AND METHODS}

The materials were sampled from the breeding colony of cormorants at Katy Rybackie, which is situated on the territory of an ornithological reserve (14.1 ha) close to Vistula Lagoon ( $54^{\circ} 21^{\prime} \mathrm{N}, 19^{\circ} 14^{\prime} \mathrm{E}$ ) in northern Poland (Figure 1). This colony developed parallely to environmental changes observed in Vistula Lagoon : increase of organic pollution, decrease of water clearness, loss of submerged aquatic vegetation, limitation of pike, increase in number of ruffe and small bank fishes. In May - June 1995, the colony of cormorants reached more than 20000 individuals (STEMPNIEWICZ, 1995). From among 18 fish species, which composed the diet of cormorants, the most important ones were ruffe, roach, herring, perch, pike-perch (MARTYNIAK et al., 1995).

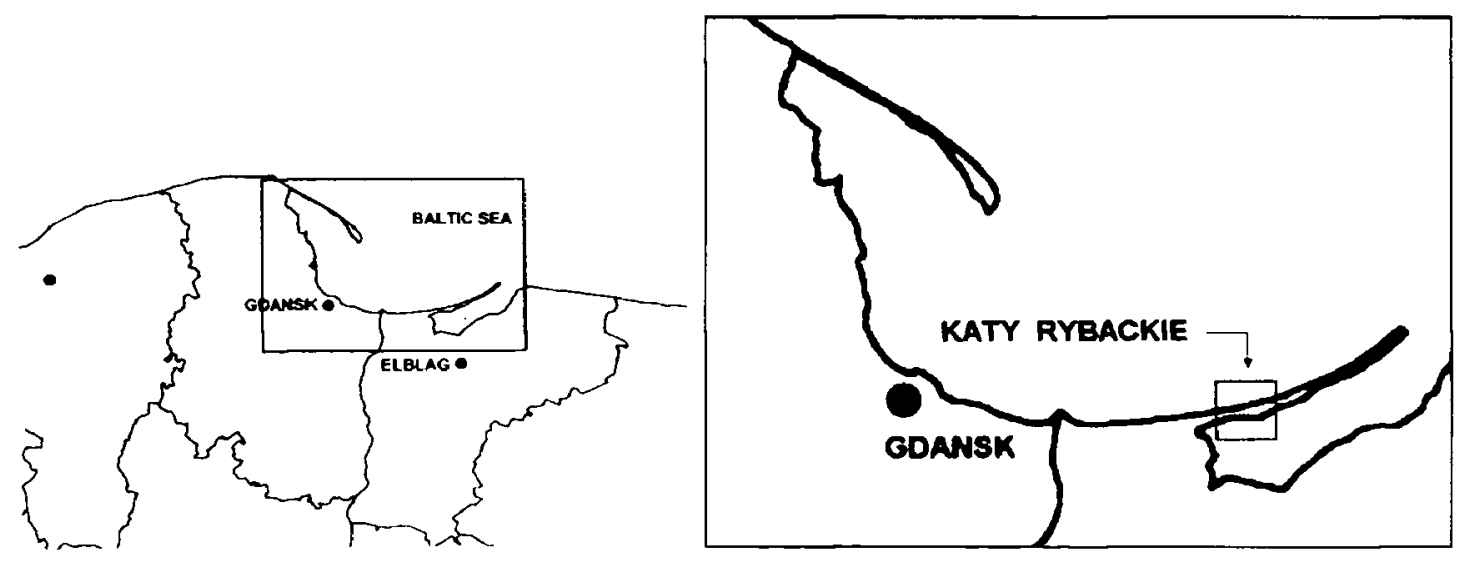

Figure 1

Location of studied sites.

Figure 1

Localisation des sites d'étude. 
During April - June 1996, fish regurgitated by cormorants Phalacrocorax carbosinensis were sampled for parasitological analysis. All the collected fish were frozen for further examination. The fishes were dissected and swim-bladders removed, organs with surrounding mesenteric tissues were pressed between glass plates and examined under a light microscope. Some drops of glycerine were added on a slide and nematodes were identified according to MORAVEC (1994).

\section{RESULTS}

The swim-bladders of 7 species of fish (herring, stickleback, perch, ruffe, pike-perch, bream and roach) were examined for the presence of $A$. crassus (Table I). From among 7 fish species whose swim-bladders were analysed, the presence of A. crassus Kuwahara, Niimi et Itagaki, 1974 was stated only in ruffe. The prevalence of the infection was $33.3 \%$. Third stage larvae of nematode were discovered in swim-bladder

\section{Table 1}

Prevalence of $\boldsymbol{A}$. crassus larvae in cormorant's prey fish in Vistula Lagoon, Poland (1996).

\section{Tableau I}

Prévalence des larves d'Anguillicola crassus dans les poissons éliminés par les cormorans, dans la Baie de Vistule en Pologne (1996).

\begin{tabular}{|c|c|c|c|c|}
\hline Fish species & $\mathbf{n}$ & $\begin{array}{l}\text { Length } \\
\bar{x} \text { (range) } \mathbf{c m}\end{array}$ & $\begin{array}{l}\text { Date of } \\
\text { sample }\end{array}$ & $\begin{array}{c}\text { Prevalence } \\
(\%)\end{array}$ \\
\hline $\begin{array}{l}\text { Clupea } \\
\text { harengus } \\
\text { (herring) }\end{array}$ & 12 & $20.9(13.8-30.6)$ & $\begin{array}{l}\text { April } \\
\text { May }\end{array}$ & 0 \\
\hline $\begin{array}{l}\text { Gasterosteus } \\
\text { aculeatus } \\
\text { (stickleback) }\end{array}$ & 2 & $(5.9-6.2)$ & May & 0 \\
\hline $\begin{array}{l}\text { Perca fluviatilis } \\
\text { (perch) }\end{array}$ & 3 & $13.2(8.4-15.8)$ & May & 0 \\
\hline $\begin{array}{l}\text { Gymnocephalus } \\
\text { cemuus } \\
\text { (ruffe) }\end{array}$ & 42 & $9.6(6.1-12.6)$ & $\begin{array}{l}\text { April } \\
\text { May } \\
\text { June }\end{array}$ & 33.3 \\
\hline $\begin{array}{l}\text { Stizostedion } \\
\text { lucioperca } \\
\text { (pike-perch) }\end{array}$ & 12 & $22.7(13.9-32.8)$ & $\begin{array}{l}\text { April } \\
\text { May } \\
\text { June }\end{array}$ & 0 \\
\hline $\begin{array}{l}\text { Abramis brama } \\
\text { (bream) }\end{array}$ & 5 & $25.3(22.8-28.3)$ & April & 0 \\
\hline $\begin{array}{l}\text { Rutilus rutilus } \\
\text { (roach) }\end{array}$ & 7 & $15.6(12.3-19.8)$ & $\begin{array}{l}\text { April } \\
\text { May }\end{array}$ & 0 \\
\hline
\end{tabular}


wall. Mean intensity of infection was 1.57 larva per infected fish. The maximum intensity was 5 larvae per fish and occurred in group of ruffe from size class $9.1-11.0 \mathrm{~cm}$. Prevalence of infection was higher in longer fish. The mean abundance was 0.52 larva per examined fish.

\section{DISCUSSION - CONCLUSION}

At present, it is difficult to resolve the question concerning the role of cormorants in the development of anguillicolosis in Vistula Lagoon (VL). It is not clear whether cormorants prefer $A$. crassus infected, or healthy fish. But it is a fact that out of the 7 examined fish species : only ruffe, a dominant species (58\% of weight) in the food of cormorant in VL (MARTYNIAK et al., 1995), was infected.

Basing on the data of STEMPNIEWICZ (1995), who evaluated the consumption of the cormorants as about $800 \mathrm{t}$ of fish per season, we can expect that cormorants can remove from the water and transfer, ashore to the breeding colony, about 150 t of infected ruffe during one season (March - August). We can suppose that sampled fish originated from a fish bank, as cormorants from VL prey upon shoals (STEMPNIEWICZ, 1995). The additional study is necessary to compare $A$. crassus infection in fish from shoals and others.

\section{Table II}

Anguillicola crassus 3rd stage larvae infection in ruffe Gymnocephalus cernuus from different water bodies.

\section{Tableau II}

Infestation des larves d'Anguillicola crassus de 3ème stade chez la grémille Gymnocephalus cernuus, dans différents plans d'eau.

\begin{tabular}{|c|c|c|c|c|c|}
\hline Localization & $\begin{array}{c}\text { Prevalence } \\
\text { of } \\
\text { infection } \\
(\%) \\
\end{array}$ & $\begin{array}{c}\text { Mean } \\
\text { intensity } \\
\text { larvae } \\
\text { per fish }\end{array}$ & $\begin{array}{c}\text { Fish } \\
\text { (n) }\end{array}$ & $\bar{x}(\mathrm{~cm})$ & References \\
\hline $\begin{array}{c}\text { Lake Velence } \\
\text { Hungary }\end{array}$ & 100.0 & 184.0 & (77) & 6.8 & $\begin{array}{l}\text { PAZOOKI and } \\
\text { SZEKELY, } 1994\end{array}$ \\
\hline $\begin{array}{c}\text { Lake Balaton } \\
\text { Hungary }\end{array}$ & 100.0 & 64.3 & (17) & 7.5 & SZÉKELY, 1994 \\
\hline $\begin{array}{l}\text { Albert Canal } \\
\text { Belgium }\end{array}$ & 95.7 & 20.6 & (209) & 8.8 & $\begin{array}{l}\text { THOMAS and } \\
\text { OLLEVIER, } 1992\end{array}$ \\
\hline $\begin{array}{l}\text { IJsselmeer } \\
\text { The Netherlands }\end{array}$ & 80.0 & 2.5 & (45) & 7.7 & $\begin{array}{l}\text { HAENEN and } \\
\text { VAN BANNING, } \\
1990\end{array}$ \\
\hline $\begin{array}{l}\text { IJsselmeer } \\
\text { The Netherlands }\end{array}$ & 100.0 & 6.9 & $(50)$ & 6.5 & $\begin{array}{l}\text { HAENEN and } \\
\text { VAN BANNING, } \\
1990\end{array}$ \\
\hline $\begin{array}{l}\text { Vistula Lagoon } \\
\text { Poland }\end{array}$ & $33.3^{*}$ & 1.6 & (42) & 9.6 & $\begin{array}{l}\text { WLASOW et al., } \\
\text { this paper }\end{array}$ \\
\hline
\end{tabular}

* Cormorant's prey fish only 
Low prevalence and intensity of $A$. crassus infection in comparison with higher respective values observed in ruffe from Hungary, Belgium and the Netherlands (Table II) can support the opinion about a lower intensity of infection of this nematode in brackish water (DEKKER and VAN WILLIGEN, 1987). Another probable reason of lower infection observed in VL is seasonal preferences of ruffe of feeding on fish eggs, or probably death of the most infected hosts.

\section{REFERENCES}

BELPAIRE C., DE CHARLEROY D., GRISEZ L., OLLEVIER F., 1989. Spreading mechanisms of the swim-bladder parasite Anguillicola crassus in European eel Anguilla anguilla and distribution in Belgium and Europe. EIFAC - Working Group on Eel, Porto, May 29th - June 3rd, 1989, 1-13.

DE CHARLEROY D., THOMAS K., BELPAIRE C., 1987. Problems concerning the species determinations, biology and diagnostical methods of Anguillicola, a swim-bladder nematode in the European eel (Anguilla anguilla L.). EIFAC - Working Group on Eel, Bristol, April 13-16, 1987, 1-7.

DEKKER W., VAN WILLIGEN J., 1987. Short note on the distribution and abundance of Anguillicola in the Netherlands. EIFAC - Working Group on Eel, Bristol, April 13-16, 1987.

EGUSA S., 1979. Notes on the culture of the European eel (Anguilla anguilla L.) in Japanese eel-farming ponds. Rapp. P.-V. Réun. Cons. Int. Explor. Mer., 174, 51-58.

HAENEN O.L.M., VAN BANNING P., 1990. Detection of larvae of Anguillicola crassus (an eel swim-bladder nematode) in freshwater fish species. Aquaculture, 87, 103-109.

HÖGLUND J., ANDERSON J., 1993. Prevalence and abundance of Anguillicola crassus in the European eel (Anguilla anguilla) at a thermal discharge site on the Swedish coast. J. Appl. Ichthyol., 9, 115-122.

KOOPS H., HARTMANN F., 1987. Infection of eels from different regions with Anguillicola. EIFAC - Working Group on Eel, Bristol, April 13-16, 1987.

MARTYNIAK A., TERLECKI J., BORON S., HLIWA P., GABRYS B., SZYMANSKA U., ROMANIEWICZ A., 1995. Food composition of the cormorant Phalacrocorax carbosinensis from Katy Rybackie colony, N Poland. Proc. IV European Conf. on Cormorants, Bologna, 1-3 November 1995, Italy, 1-5.

MORAVEC F., 1994. Parasitic nematodes of freshwater fishes of Europe. Academia, Praha, $473 \mathrm{p}$.

PAGGI L., ORECCHIA P., MINERVINI R., MATTIUCCI S., 1982. Sulla comparsa di Anguillicola australiensis Johnston et Mawson, 1940 (Dracunculoloidea : Anguillicolidae) in Anguilla anguilla del Lago di Bracciano. Parasitologia, 24, 139-144.

PAZOOKI J., SZÉKELY C.S., 1994. Survey of the paratenic hosts of Anguillicola crassus in Lake Velence, Hungary. Acta Vet. Hungarica, 42(1), 87-97.

STEMPNIEWICZ L., 1995. Fish and cormorants. Report, Gdynia 1995, 1-13.

SZÉKELY C.S., 1994. Paratenic hosts for the parasitic nematode Anguillicola crassus in Lake Balaton, Hungary. Dis. aquat. Org., 18, 11-20.

THOMAS K., OLLEVIER F., 1992. Paratenic hosts of the swimbladder nematode Anguillicola crassus. Dis. aquat. Org., 13, 165-174.

WLASOW T., KUJAWA R., BERNAD A., ZIELONKA M., 1991. The occurrence of parasites of eel Anguilla anguilla L. - imported material for stocking and eels from some Polish waters. XVI Congress of Polish Parasitol. Soc., Poznan, 12-13 Sept. 1991, Poland. 